\title{
Leksykon oprawoznawczy. Realizacja projektu w ramach Narodowego Programu Rozwoju Humanistyki. Komunikat
}

\begin{abstract}
The Lexicon of bookbinding. The grant from the National Programme for the Development of Humanities. The statement of the research

The "Lexicon of bookbinding" project is going to be finalized with the electronic (published in 2019) and printed (published in 2020) versions of the lexicon. The entries covering approximately 2000 terms will be related to adequate terms in English, German, French, and Italian languages. A challenge is to order and to unify the terminology, as well as to propose Polish terms for the concepts on bookbinding which has not been defined so far.
\end{abstract}

Terminologia stanowi podstawę każdej dyscypliny naukowej, a braki w tym zakresie hamują rozwój nauki. Także postęp oprawoznawstwa wymaga skodyfikowania oraz prawidłowego i jednoznacznego zdefiniowania fachowego słownictwa, a czasami nawet stworzenia nowych terminów. Potrzebę tę uznali decydenci konkursu Narodowego Programu Rozwoju Humanistyki, przyznając w roku 2015 projektowi „Leksykon oprawoznawczy” wnioskowane finansowanie w wysokości 348 tysięcy zł. Projekt został zarejestrowany pod numerem 1aH 15031083.

Zadania podjęło się troje wykonawców, wywodzących się z różnych dyscyplin naukowych; każdy wnosi własne doświadczenie i perspektywę badawczą. Projektem kieruje Elżbieta Pokorzyńska, bibliotekoznawca z Katedry Informacji Naukowej i Bibliologii Uniwersytetu Kazimierza Wielkiego (UKW) w Bydgoszczy, zajmująca się badaniem introligatorstwa XIX-XX w., 
rzemiosła i przemysłu, jego historii, organizacji i sztuki. Małgorzata Pronobis-Gajdzis, konserwator z Zakładu Konserwacji Papieru i Skóry Uniwersytetu Mikołaja Kopernika w Toruniu, wnosi wiedzę i praktyczne doświadczenie pracy z dawnymi oprawami, znajomość technik introligatorskich i elementów opraw z różnych epok oraz kręgów kulturowych. Arkadiusz Wagner, historyk sztuki i bibliolog z Instytutu Informacji Naukowej i Bibliologii UMK, jest specjalistą w zakresie opraw artystycznych z dawnych wieków.

Wstępny etap realizacji projektu polegał na zapoznaniu się z innymi opracowaniami o zbliżonej tematyce. W polskiej bibliologii dysponujemy dwoma wydawnictwami leksykalnymi, obejmującymi tematykę introligatorską. Powstały one w różnych środowiskach i różnią się tak dalece, jakby opisywały zupełnie inną rzeczywistość.

Korpus haseł oprawoznawczych w Encyklopedii wiedzy o ksiażce (Wrocław 1971) został przygotowany przez doświadczonych bibliologów pod ogólną redakcją Aleksandra Birkenmajera. Redaktorem działu oprawoznawczego była Anna Lewicka Kamińska, zaś hasła poświęcone historii sztuki oprawy opracowała Maria Jarosławiecka-Gąsiorowska. Encyklopedia zawiera około 250 haseł poświęconych introligatorstwu, w tym technologii, materiałom, czynnościom, częściom, typom i zdobnictwu opraw, osobom związanym $\mathrm{z}$ introligatorstwem oraz dziejom tego rzemiosła w różnych ośrodkach krajowych i zagranicznych. Zagadnienia artystyczno-historyczne, zwłaszcza artykuły poświęcone oprawom średniowiecznym i renesansowym, zostały opracowane obszernie i kompetentnie, co było owocem zainteresowania autorów oprawami z tego okresu. Problemy oprawoznawcze dotyczące wieków późniejszych oraz zagadnienia technologiczne zostały opisane słabiej; hasła po części są wtórne w stosunku do podobnych w wydawnictwach obcych, inne są skrótowe, ogólnikowe, przypadkowe czy wręcz niekompletne.

Wydany we Wrocławiu w 1986 r. w serii Książki o Książce słownik Wspótczesne polskie introligatorstwo i papiernictwo pod redakcją Jerzego Celmy-Panka (introligatorstwo) i Stefana Libiszowskiego (papiernictwo) zawiera 160 haseł. Zdecydowana większość z nich dotyczy zagadnień przemysłu introligatorskiego, są one obszerne i szczegółowe, ale dziś w dużym stopniu zdezaktualizowane. Zupełnie marginalnie ujęto zagadnienia związane z rzemiosłem introligatorskim oraz z oprawoznawstwem historycznym. Nie dość, że hasła są nieliczne, to jeszcze opracowano je niekompetentnie, wybiórczo, pobieżnie, a nawet z błędami. Niedostatki merytoryczne są konsekwencją składu autorskiego, zdominowanego przez specjalistów od zagadnień poligraficznych, do których dokooptowano konserwatora oraz profesjonalnego redaktora.

Także w sferze terminologicznej obie encyklopedie ukazują rozbieżności: EWOK stosuje tradycyjne nazwy używane w rzemiośle introligatorskim od wieków, w tym szereg germanizmów, tymczasem we Współczesnym polskim 
introligatorstwie dominują nazwy obowiązujące w słownictwie poligrafii, ustalone przez polskie normy. Są to wyrazy ściśle polskie, utworzone z inspiracji teoretyków poligrafii w latach powojennych. Czytelnik napotyka zatem na równoległe zestawy terminów, nie wiedząc czy są synonimami i nie orientując się, których należy użyć w konkretnych okolicznościach.

Obok encyklopedii polskich przeanalizowano także wiele analogicznych publikacji zagranicznych. Z jednej strony poszukiwano w nich właściwej formy dla naszej pracy, z drugiej - tworzono listę haseł, które należy wprowadzić do naszego leksykonu. Spotkano się z szeroką gamą rozwiązań: od encyklopedii o rozbudowanych artykułach i bogatej warstwie ilustracyjnej (Dizionario illustrato della legatura Federica i Livia Macchich, Mediolan 2002), przez leksykony przeznaczone dla introligatorów (Buchbinder ABC Gustava Moessnera, Bergisch Gladbach 1981), konserwatorów (Glossary of basic archival and library conservation terms... ${ }^{1}$ Carmen Crespo Nogueiry, Monachium 1988) lub bibliofilów (ABC of bookbinding... Jane Greenfield, New Castle 1998), aż po tezaurusy terminologiczne (Language of Bindings Nicolasa Pickwooda i jego grupy Ligatus, dostępny online ${ }^{3}$ oraz Binding terms...4, Chicago 1988) i słowniki wielojęzyczne (Wörterbuch der Handbuchbinderei und der Restaurierung von Einbänden... ${ }^{5}$ Hildy Kuhn, pierwsze wydanie Stuttgart 1969). We wstępnej fazie realizacji projektu nasz zachwyt wzbudził leksykon Bookbinding and the conservation of books... ${ }^{6}$ Matta T. Robertsa i Dona Etheringtona (Waszyngton 1982), który zawiera wielką liczbę zwięźle opracowanych haseł (ok. 4000), dotyczących głównie technologii i budowy opraw. Jednak wraz z rozwojem prac zdecydowano się na hasła dłuższe, bardziej rozbudowane, integrujące szereg drobnych elementów, bardziej zbliżone do włoskiego Dizionario illustrato della legatura.

W określeniu pola badawczego skupiono się na elementach morfologicznych, technikach wykonawczych i zdobniczych, typologii i motywach

\footnotetext{
1 Glossary of basic archival and library conservation terms: English with equivalents in Spanish, German, Italian, French and Russian.

2 ABC of bookbinding. A unique glossary with over 700 illustrations for collectors and librarians.

LoB, [online] http://www.ligatus.org.uk/lob/ [dostęp 07.08.2018].

4 Binding terms. A thesaurus for use in rare book and special collections cataloguing.

5 Wörterbuch der Handbuchbinderei und der Restaurierung von Einbänden, Papyri, Handschrifren, Graphiken, Autographen, Urkunden und Globen in deutscher, englischer, französischer und italienischer Sprache = Dictionary of bookbinding and restauration of papyri, manuscripts, engravings, autographs, documents, bindings and globes in German, English, French and Italian = Dictionnaire de la reliure et de la restauration des papyri, manuscrits, estampes, autographes, documents, reliures et globes en allemand, anglais, français et italien = Dizionario della legatura e del restauro dei papiri, manoscritti, opere grafiche, autografi, documenti, legature e globi nelle lingue tedesca, inglese, francese ed italiana.

6 Bookbinding and the conservation of books. A dictionary of descriptive terminology.
} 
dekoracyjnych opraw oraz narzędziach i materiałach introligatorskich. Z zagadnień historycznych i organizacyjnych pozostawiono grupę haseł najbardziej ogólnych i podstawowych, których nie można pominąć, podobnie jak haseł biograficznych. Zdecydowano do minimum ograniczyć tematy dotyczące przemysłu introligatorskiego, skupiając się na jego początkach, a pomijając stan dzisiejszy. Hasła, obok podania podstawowej faktografii o zakresie ogólnym, będą akcentować dzieje polskiego introligatorstwa, przedstawiać rodzime zabytki i artefakty.

W wyniku prac wstępnych sporządzono listę terminów do opracowania liczącą około 2000 pozycji. Ambicją autorów jest skonfigurowanie haseł $\mathrm{z}$ adekwatnymi terminami obcojęzycznymi: angielskimi, niemieckimi, francuskimi i włoskimi. Poważnym wyzwaniem jest uporządkowanie i ujednolicenie terminologii oraz utworzenie brakujących nazw polskich, co wymaga współpracy innych osób. W tym celu organizowane są sesje robocze grona konsultantów z różnych regionów i środowisk (bibliotekarze, konserwatorzy, introligatorzy) przy udziale językoznawcy.

Realizacja grantu jest doskonałą okazją do uaktualnienia wiedzy oprawoznawczej. Polskie zbiory są ubogie w publikacje o tej tematyce, dostępne opracowania są przeważnie starsze, rozproszone po wielu bibliotekach. Brak wspólnej platformy informacyjnej o publikacjach z zakresu introligatorstwa i oprawoznawstwa oraz trudny do nich dostęp są także barierą rozwoju w Polsce tej subdyscypliny bibliologicznej. Dlatego aby zapoznać się z wartościową literaturą przedmiotu uczestnicy grantu w 2017 r. odbyli wyjazd studyjny do Berlina, gdzie w Bibliotece Państwowej - Fundacji Pruskiego Dziedzictwa Kulturalnego (Staatsbibliothek zu Berlin - Preußischer Kulturbesitz), dawnej Bibliotece Królewskiej, później Pruskiej Bibliotece Państwowej, jednej z największych książnic na świecie, od stuleci gromadzone są publikacje bibliologiczne. Zasób literatury oprawoznawczej tam zebranej przerósł nasze wyobrażenia. Cztery dni zostały wypełnione przeglądem literatury udostępnianej w czytelni podręcznej. Nie starczyło sił ani czasu na analizę czasopism ani zamawianie innych książek, przechowywanych w magazynach. Na podstawie przeprowadzonej kwerendy powstaje bibliografia, prowadzone są zakupy najcenniejszych publikacji, niektóre książki zostały zeskanowane na miejscu, w berlińskiej bibliotece. Tworzony w ten sposób warsztat naukowy będzie służyć nie tylko do przygotowania leksykonu, ale zasili krajowy zasób publikacji dziedzinowych i będzie udostępniany wszystkim badaczom.

Licząc się z wymogami współczesności zdecydowano się na dwojaką postać leksykonu: cyfrową i drukowaną. Leksykon w postaci cyfrowej jest zbudowany na oprogramowaniu Wiki, a autorem platformy jest Paweł Marzec, informatolog z Instytutu Informacji Naukowej i Bibliologii UMK (wcześniej Katedry Informacji Naukowej i Bibliologii UKW). Poszczególne hasła 
mogą, zależnie od obszerności, być podzielone na podrozdziały oraz zaopatrzone we własną bibliografię, odsyłacze i ilustracje, zarówno fotograficzne, jak i rysunkowe. Platforma internetowa ma obecnie charakter roboczy i jest dostępna wyłącznie wykonawcom projektu. Po zakończeniu prac zostanie udostępniona do publicznego użytku. Materiał tekstowy i ilustracyjny zostanie zredagowany i opublikowany również w tradycyjnej postaci książkowej. Harmonogram przewiduje zakończenie fazy tworzenia leksykonu cyfrowego na 2019, a jego wydanie książkowe na $2020 \mathrm{r}$. 